\title{
手指のしびれと環指の知覚神経活動電位
}

$\begin{array}{ccccc}\text { 山口大学医学部整形外科 } & & & \\ \text { 白 } & \text { 石 } & & \text { 元・河 } & \text { 合 伸 也 } \\ \text { 淵 } & \text { 上 泰 } & \text { 敬・金 子 和 生 } \\ \text { 長 } & \text { 井 } & & \text { 英 ・河 村 洋 行 } \\ \text { 土 } & \text { 聖 } & \text { 司・村 } \text { 田 洋一郎 }\end{array}$

\section{Clinical Validation of Sensory Conduction in the Ring Finger associated with Hand Numbness}

by

\author{
Gen Shiraishi, Shinya Kawai, Yasunori Fuchigami, Kazuo Kaneko, \\ Ei Nagai, Hiroyuki Kawamura, Seiji Tsuchida and Youichirou Murata \\ Department of Orthopaedic Surgery, School of Medicine, \\ Yamaguchi University, 1144 Kogushi, Ube, Japan
}

\begin{abstract}
Median and ulnar sensory nerve conduction velocities and amplitudes were measured orthodromically on the ring finger in 10 normal hands and in 64 hands with numbness ( 31 hands with carpal tunnel syndrome (CTS), 16 hands with cubital tunnel syndrome(CubTS), 8 hands with paresthesia due to cervical spondylosis(CS) and 9 hands with diabetic neuropathy(DN)). Of 31 hands with CTS, 13 hands had slow conduction velocities $(35.6 \pm 7.3 \mathrm{~m} / \mathrm{s})$ and 18 hands had no sensory nerve action potential (SNAP) in the median nerve. Of 16 hands with CubTS, 12 hands had no SNAP and 4 had normal ulnar nerve conduction velocities. Nine hands with DN had low amplitudes and slow conduction velocities in both nerves. Eight hands with CS had normal SNAPs in both nerves. We concluded that measurement of SNAP of the ring finger is easy and useful for diagnosing numbness in hands.
\end{abstract}

Key words : Ring Finger (環指), Sensory Nervw Action Potential (知覚神経活動電位), Numbness (しびれ)

はじめに

日常の診療において “手指のしびれ”を訴える患者 は多い. 環指の知覚神経活動電位を測定することが簡 便で有効な補助診断になりえるか検討した。環指の指 神経の支配は橈側が正中神経, 尺側が尺骨神経支配に 二分されていることに着目して，環指を刺激すること が同時に正中神経と尺骨神経を刺激することになり， 末梢神経障害の鑑別に有用と考えた。
方

法

環指の知覚神経活動電位の測定方法は環指をリング 電極を用いて刺激し，手関節の正中神経と尺骨神経よ り表面電極を用いて同時に記録する，順行性の測定方 法である.刺激の持続時間は $0.2 \mathrm{msec}$, 頻度は $3 \mathrm{~Hz}$, 強度は感覚闇值の約 3 倍とし, 記録は約 50 回の平均 加算とした. 


\section{対}

象

健常人 10 人（平均 29 才）をコントロールとし, 整 形外科の外来で “手指のしびれ”を訴える患者を対象 とした。 その内訳は手根管症候群 31 手 (22人), 时 部管症候群 16 手 (13人), 頸椎症 8 手 ( 5 人), 糖尿 病性ニューロパチー 9 手 ( 7 人), 計 64 手である. 平 均年齢はいずれも 50 才前後である.

\section{結果}

健常人 10 人を対象としたコントロールでは正中神 経, 尺骨神経ともに伝導速度は $50.60 \mathrm{~m} / \mathrm{s}$ ，振幅は 10 $\mu \mathrm{V}$ 前後であった。 また正中神経，尺骨神経を同時に 刺激しているためにたとえば正中神経より記録した場 合の電位に正中神経からの近接電位だけではなく尺骨 神経からの容積伝導を介した電位も含まれることに注 意する必要がある。たとえば正中神経支配である中指 を刺激して尺骨神経から電位を測定したところ正中神 経の電位の約 $1 / 4$ から $1 / 5$ の振幅で潜時が等しい電位 が記録された。同様なことが小指刺激の場合もあては まり容積伝導を介した遠隔電位と近接電位を区別する 必要がある。

手根管症候群は 2 つのパターンを示した. 1 つは 2 つのピークをもつ場合である. 最初のピークは尺骨神 経の容積伝導であり, 後のピークは伝導速度が低下し た正中神経のピークである，もう一つのパターンは後 のピークが消失している場合で正中神経からの電位が 得られない場合である. 31 手のうち前者が 13 手, 後 者が 18 手あった（図 1 ). 次に肘部管症候群は多くの 場合は尺骨神経の電位が得られない場合で 16 手のう ち 12 手で電位が消失していた。残りの 4 手は正常か あるいは振幅は低下するものの伝導速度は正常であっ た (図 2 ). 次に頸椎症では正中神経, 尺骨神経とも に正常であった．また糖尿病性ニューロパーチーでは 正中神経，尺骨神経ともに振幅低下，消失を示すもの が多かった (図 3 ). 環指の知覚神経活動電位の測定 で正中神経と尺骨神経から得られた波形のパターンか ら手根管症候群, 时部管症候群, 頸椎症, 糖尿病性ニュー ロパチーは表 1 の如く鑑別可能であった。

\section{考察}

“手指のしびれ”の原因はさまざまで，大まかに言っ て未梢神経障害, 脊椎, 脊髄病変, 脳血管障害・脳腫

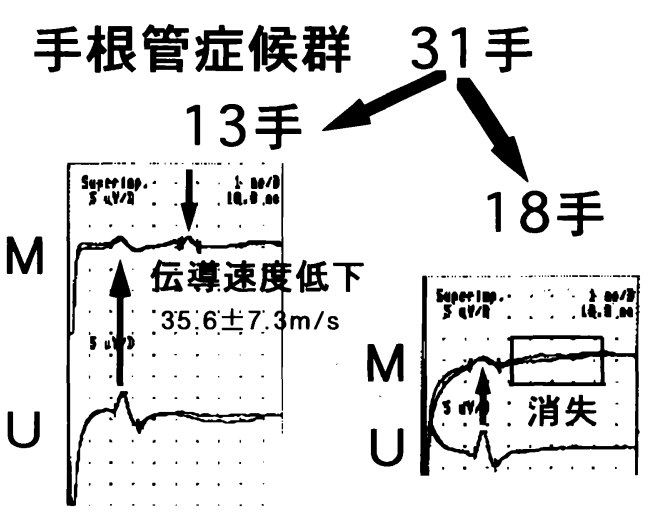

図 1 手管根症候群：環指を刺激して手関節で正中神経 （M）と尺骨神経（U）から順行性に記録した波形 である，左の波形は正中神経（M）で伝導速度低下 を示し，右の波形は正中神経（M）で消失を示す.

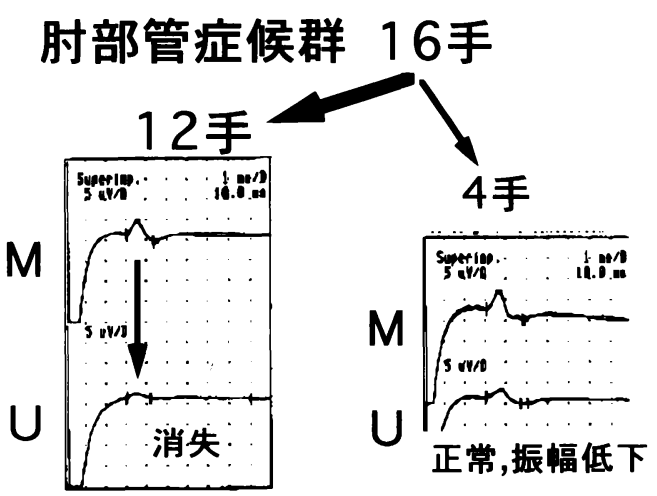

図 2 时部管症候群：左の波形は尺骨神経（U）で消失 を示し，右の波形は尺骨神経（U）で正常，振幅低 下を示す。

瘍などの頭蓋内病変, などが挙げられ，その他循管障 害，心因性のものまで鑑別する必要がある．最近の画 像診断の進歩・特に MRの出現によって頭蓋内，脊 椎・脊髄病変の診断は飛躍的に進歩したが末梢神経に おいては依然として電気生理学的手法が最も有効な補 助診断である. “しびれ”はおもに知覚障害をあらわ しているために客観性に乏しく，これのみに頼ると診 断に失敗する。また電気生理の検査といってもまず何 からしてよいのか, また時間, 経費の節約から考えて 簡便で情報が多い検査から行う必要がある，伝導速度 や振幅を測定しても絶対值ではどこからを異常とする か迷うことが多い. その時は左右差や他のパラメー 


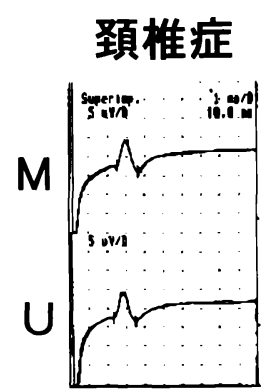

正常型
榶尿病性

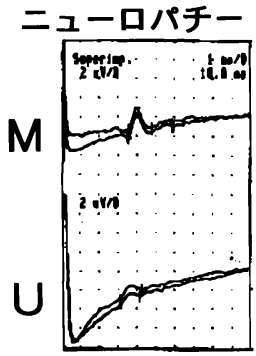

振幅低下、消失

図 3 頸椎症と糖尿病性ニューロパチー：頸椎症では正 中神経 (M) と尺骨神経 (U) ともに正常型であり, 糖尿病性ニューロパチーではともに振幅低下など異 常を示す。

表 1 環指の知覚神経活動電位を用いた “手指のしび

\begin{tabular}{|c|c|c|}
\hline 正中神経 & 尺骨神経 & 診 \\
\hline 伝導速度低下消失 & 正常 & 手根管症候群 \\
\hline 正常 & 振幅低下消失 & 肘部管症候群 \\
\hline 正常 & 正常 & 頸椎症等 \\
\hline 振幅低下 & 振幅低下 & $\begin{array}{l}\text { 糖尿病性 } \\
\text { ニューロパチー }\end{array}$ \\
\hline
\end{tabular}

ターを参考にするわけであるが正中神経と尺骨神経を 同時に測定し，比較することが異常の有無を判定する ときは特に重要である。手根管症候群の症例で示指刺

激と環指刺激を比較したところ環指刺激のほうが異常 を鋭敏に捉えることが多く，早期にまず環指が異常を 示し易いことがわかっている ${ }^{1)-3)}$ 。これは手根管部の 正中神経のトポグラフィーから第 3 指間掌側指神経の 位置が前方, 内側に位置し横手根靱帯によって圧迫さ れやすいことに起因しているものと考えられる．以上 のように環指の知覚神経活動電位を測定することは “手指のしびれ”の鑑別に簡便で多くの情報を一度に 得られる方法として推奖したい.

$$
\text { ま と め }
$$

外来でよく遭遇する“手指のしびれ”の鑑別に環指 の知覚神経活動電位の測定が簡便で有用であることを 示した。

\section{参 考 文 献}

1) Cioni, R. et al. : Diagnostic specificity of sensory and motor nerve conduction variables in early detection of carpal tunnel syndrome. J Neurol, 236 : 208-213, 1989.

2) Lauritzen, M., Liguori, R. and Trojaborg, W.: Orth odromic sensory conduction along the ring finger in normal subjects and in patients with a carpal tunnel ayndrome. Electroencephalogr Clin Neurophysiol, $81: 18-23,1991$.

3) Uncini, A. et al. : Sensitivity of three median-toulnar comparative tests in diagnosis of mild carpal tunnel syndrome. Muscle Nerve, 16:1366-1373, 1993. 